\title{
Nocardioides sediminis sp. nov., isolated from a sediment sample
}

\author{
Syed G. Dastager, Jae-Chan Lee, Yoon-Jung Ju, Dong-Jin Park \\ and Chang-Jin Kim
}

\author{
Correspondence \\ Chang-Jin Kim \\ changjin@kribb.re.kr
}

\author{
Korea Research Institutes of Biosciences and Biotechnology, 52 Eoeun-dong, Yuseong gu, \\ Daejeon 305-333, Republic of Korea
}

\begin{abstract}
A strictly aerobic, motile, short-rod-shaped, Gram-positive-staining actinomycete strain, designated $\mathrm{MSL}-01^{\top}$, was isolated from a sediment sample from Bigeum Island of Korea. 16S rRNA gene sequence analysis revealed that the isolate $\mathrm{MSL}-01^{\top}$ belonged to the genus Nocardioides, with the highest sequence similarity to Nocardioides terrigena DS $-17^{\top}(98.54 \%)$, but the DNA-DNA relatedness to this type strain was $34 \%$. The physiological properties of strain MSL-01 ${ }^{\top}$ differ from those of Nocardioides terrigena DS-17 ${ }^{\top}$ and other species of Nocardioides. The diamino acid in the cell-wall peptidoglycan of strain MSL- $01^{\top}$ is $\mathrm{LL}$-diaminopimelic acid, the major menaquinone is $\mathrm{MK}-8\left(\mathrm{H}_{4}\right)$ and iso- $\mathrm{C}_{16: 0}$ is the major fatty acid component. The name Nocardioides sediminis sp. nov. is proposed for the novel species, with the type strain MSL-01 ${ }^{\top}$ $\left(=\right.$ DSM $19263^{\top}=$ KCTC $\left.19271^{\top}\right)$.
\end{abstract}

The genus Nocardioides was proposed by Prauser (1976) for Gram-positive-staining, non-acid-fast, aerobic and mesophilic nocardioform actinomycetes that develop a mycelium that fragments into irregular rod-coccus-like elements. Originally, the genus contained the two species Nocardioides albus and Nocardioides luteus (Prauser, 1984). The number of species belonging to the genus Nocardioides has increased considerably, revealing the morphological heterogeneity of the genus. Presently, the genus includes 28 recognized species, including the recently described species Nocardioides terrigena (Yoon et al., 2007), Nocardioides marinisabuli (Lee et al., 2007), Nocardioides daphniae (Tóth et al., 2008) and Nocardioides hankookensis (Yoon et al., 2008). In this study, we report the taxonomic characterization of a Nocardioides-like strain, MSL- $01^{\mathrm{T}}$, which was isolated from a sediment sample collected on Bigeum Island, Jeollanam-do Province, Korea.

Strain MSL- $01^{\mathrm{T}}$ was isolated from a sediment sample taken during May 2006 at a depth of 60-70 m. The top $10 \mathrm{~cm}$ of the sediment surface was obtained aseptically for sampling and then processed for cultivation experiments by using standard dilution techniques at $28{ }^{\circ} \mathrm{C}$ on tenfold-diluted R2A agar (Reasoner \& Geldreich, 1985; Difco). To investigate the morphological, physiological and biochemical characteristics of strain MSL- $01^{\mathrm{T}}$, the strain was routinely cultivated at $28{ }^{\circ} \mathrm{C}$ on twofold-diluted R2A agar and the strain was stored as glycerol suspensions $(20 \%$, $\mathrm{v} / \mathrm{v}$ ) at $-70{ }^{\circ} \mathrm{C}$. Gram staining was performed using a bioMérieux Gram-stain kit according to the manufac-

The GenBank/EMBL/DDBJ accession number for the 16S rRNA gene sequence of strain MSL- $01^{\top}$ is EF466110. turer's instructions. Cell morphology and motility were studied using phase-contrast and scanning electron microscopy (JEOL apparatus Philips SEM 515). The physiological characteristics of strain MSL- $01^{\mathrm{T}}$ were examined by growing the isolate on diluted R2A medium. Growth at various temperatures $\left(4-50{ }^{\circ} \mathrm{C}\right)$ was measured on twofolddiluted R2A agar. Growth at different $\mathrm{pH}$ levels ( $\mathrm{pH}$ 6.012.0) was determined after adjusting the $\mathrm{pH}$ of the medium by the addition of $\mathrm{Na}_{2} \mathrm{CO}_{3}$ prior to sterilization. Growth at various $\mathrm{NaCl}$ concentrations $(0-20 \% \mathrm{w} / \mathrm{v})$ was investigated on twofold-diluted R2A agar. Catalase and oxidase activities and hydrolysis of starch, casein, gelatin, hypoxanthine, Tween 80, tyrosine, urea and xanthine were determined as described by Cowan \& Steel (1965). Oxidase activity was tested by assessing the oxidation of $1 \%(\mathrm{w} / \mathrm{v})$ tetramethyl- $p$-phenylenediamine (Merck) and catalase activity was evaluated by assessing the production of bubbles from a $3 \%(\mathrm{v} / \mathrm{v})$ aqueous $\mathrm{H}_{2} \mathrm{O}_{2}$ solution. Hydrolysis of aesculin and nitrate reduction were studied as described previously by Lányí (1987). Enzyme activities were determined by using the API ZYM system (bioMérieux); detailed information is given in the species description. Utilization of various substrates as sole sources of carbon and energy was determined as described by Shirling \& Gottlieb (1966).

Cell walls were purified and peptidoglycan amino acids were analysed by TLC as described by Lechevalier \& Lechevalier (1980). Analysis of the whole-cell sugar composition followed procedures described by Becker et al. (1965). Phospholipid analysis was carried out as described by Lechevalier et al. (1981). Menaquinones were determined using the procedures of Collins et al. (1977). 
Cell biomass for DNA extraction and for analysis of cell walls and isoprenoid quinones was obtained by cultivation in $\mathrm{R} 2 \mathrm{~A}$ broth at $28{ }^{\circ} \mathrm{C}$ for 7 days. For fatty acid methyl ester analysis, cell mass of strain MSL- $01^{\mathrm{T}}$ was harvested from R2A plates after incubation at $28{ }^{\circ} \mathrm{C}$ for 7 days. The fatty acids were extracted, methylated and analysed using the standard MIDI (Microbial Identification) system (Sasser, 1990; Kämpfer \& Kroppenstedt, 1996). Analyses of isoprenoid quinones were carried out using the methods described by Komagata \& Suzuki (1987). The G+C content of the genomic DNA of strain MSL-0 $1^{\mathrm{T}}$ was determined using an HPLC apparatus fitted with a reversed-phase column (GROM-SIL 100 ODS-2FE; GROM), according to the method of Tamaoka \& Komagata (1984).

Strain MSL- $01^{\mathrm{T}}$ formed cream-white, glistening, translucent, slightly sticky, irregular and slightly raised colonies when grown on R2A agar at $28{ }^{\circ} \mathrm{C}$ for 2 days. Growth was observed at $20-37{ }^{\circ} \mathrm{C}$; optimum growth occurred at $28{ }^{\circ} \mathrm{C}$ and $\mathrm{pH} 7.0-7.5$. Cells of the isolate were motile, short, irregular rods $(0.3-0.8 \mathrm{~mm}$ wide and $0.9-1.4 \mu \mathrm{m}$ long) without any flagella (Fig. 1). Cells of strain MSL-01 ${ }^{\mathrm{T}}$ strained Gram-positive and were oxidase-negative and catalase-positive and reduced nitrate to nitrite. Growth was not observed under anaerobic conditions after 5 days at $28{ }^{\circ} \mathrm{C}$ on R2A agar. The major respiratory lipoquinone of strain MSL- $01^{\mathrm{T}}$ was MK- $8\left(\mathrm{H}_{4}\right)$. The fatty acid profile of the strain showed a predominance of fatty acids iso- $\mathrm{C}_{16: 0}$ (48.3\%), $\mathrm{C}_{17: 1} \omega 8 c(17.1 \%)$, iso- $\mathrm{C}_{17: 0}(7.0 \%), 10$-methyl $\mathrm{C}_{17: 0}(4.8 \%)$ and $\mathrm{C}_{18: 1} \omega 9 c(4.3 \%)$. Similar fatty acid profiles have been reported for type strains of the genus Nocardioides. The G $+\mathrm{C}$ content of the genomic DNA of strain MSL-01 ${ }^{\mathrm{T}}$ was $71.5 \mathrm{~mol} \%$.

In Table 1, the phenotypic characteristics of strain MSL$01^{\mathrm{T}}$ are summarized and compared with those of the type strains of closely related species. Members of the genus Nocardioides possess iso- $\mathrm{C}_{16: 0}$ as the major fatty acid and

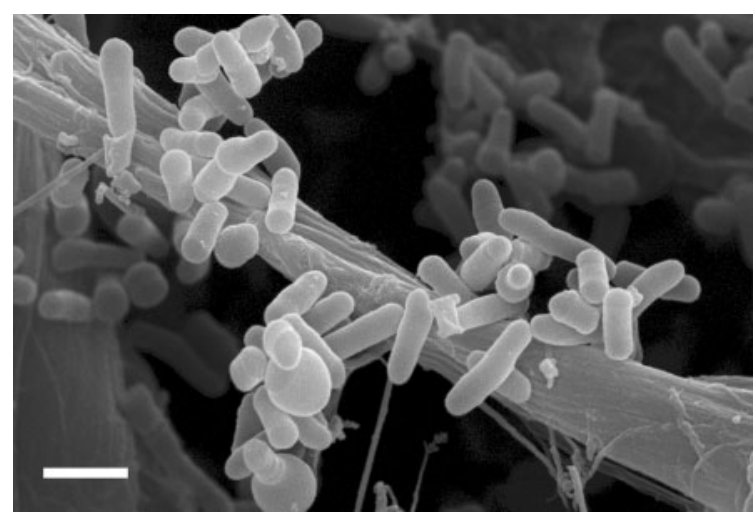

Fig. 1. Scanning electron micrograph of cells of strain MSL-01 ${ }^{\top}$ grown on R2A agar for 5 days at $30{ }^{\circ} \mathrm{C}$. Bar, $1.0 \mu \mathrm{m}$. have DNA G+C contents in the range $67-74 \mathrm{~mol} \%$ (Prauser, 1976, 1984; Yoon \& Park, 2006). Strain MSL-01 ${ }^{\mathrm{T}}$ possesses phenotypic characteristics typical of the genus Nocardioides.

Genomic DNA extraction and PCR amplification of the 16S rRNA gene of strain MSL- $01^{\mathrm{T}}$ were carried out using the procedure of Chun \& Goodfellow (1995). An almostcomplete 16S rRNA gene sequence (1437 nt) was obtained from strain MSL- $01^{\mathrm{T}}$. The sequence of strain MSL- $01^{\mathrm{T}}$ was compared with $16 \mathrm{~S}$ rRNA gene sequences available in GenBank by using the BLAST program (http:// www.ncbi.nlm.nih.gov/blast/) to determine the approximate phylogenetic affiliation and the sequence was then aligned with those of its close relatives by using the CLUSTAL W software (Thompson et al., 1994). Phylogenetic trees were generated based on the neighbour-joining (Saitou \& Nei, 1987), maximum-parsimony (Kluge \& Farris, 1969) and maximum-likelihood (Felsenstein, 1981) algorithms. Phylogenetic analysis based on $16 \mathrm{~S}$ rRNA gene sequences showed that strain MSL- $01^{\mathrm{T}}$ formed a distinct, monophyletic cluster with $N$. terrigena DS- $17^{\mathrm{T}}$ (Fig. 2). The topologies of trees built using the maximum-likelihood and maximum-parsimony algorithms also supported the notion that the isolate belongs to the genus Nocardioides (not shown). Comparative 16S rRNA gene sequence analyses showed that the isolate was most closely related to $N$. terrigena DS- $17^{\mathrm{T}}$, having a similarity of $98.54 \%$. Because of the high pairwise similarity between strain MSL- $01^{\mathrm{T}}$ and $N$. terrigena DS$17^{\mathrm{T}}$, the DNA-DNA relatedness of these two strains was determined. The value obtained was $34 \%$, which is well below the threshold value of $70 \%$ recommended for the definition of bacterial species (Wayne et al., 1987). Sequence similarities to other members included in the phylogenetic analysis ranged from 97.38 to $94.87 \%$. Thus, on the basis of the physiological, biochemical and phylogenetic properties of strain MSL- $01^{\mathrm{T}}$, this isolate represents a novel species within the genus Nocardioides, for which the name Nocardioides sediminis sp. nov. is proposed.

\section{Description of Nocardioides sediminis sp. nov.}

Nocardioides sediminis (se.di.mi'nis. L. n. sedimen a sediment; L. gen. n. sediminis of a sediment, referring to the source from which the type strain was isolated).

Gram-positive-staining, motile without any flagellum, aerobic and non-spore-forming. Cells appear as short, irregular rods, approximately $0.3-0.8 \times 0.9-1.4 \mu \mathrm{m}$ after $72 \mathrm{~h}$ incubation at $28{ }^{\circ} \mathrm{C}$. Colonies are cream-whitish, glistening, translucent, slightly sticky, irregular and slightly raised with entire margins. Optimum growth at $28{ }^{\circ} \mathrm{C}$ and $\mathrm{pH} 7.0-7.5$. Positive for catalase test and negative for oxidase test. Casein, gelatin, starch and Tween 80 are hydrolysed but aesculin, hypoxanthine and xanthine are not decomposed. Nitrate is reduced to nitrite and urea hydrolysis is negative. Positive for 
Table 1. Differential phenotypic characteristics of strain $\mathrm{MSL}-01^{\top}$ and the type strains of phylogenetically related Nocardioides species

Strains: 1, MSL-01 ${ }^{\mathrm{T}} ; 2$, N. terrigena DS- $17^{\mathrm{T}} ; 3$, N. aquiterrae GW-9 ${ }^{\mathrm{T}} ; 4$, N. pyridinolyticus OS4 ${ }^{\mathrm{T}}$. Data were taken from Yoon et al. $(1997,2004,2007)$ and this study. +, Positive; -, negative; w, weakly positive. All strains are positive for Gram staining, catalase, nitrate reduction, hydrolysis of casein and gelatin, utilization of D-xylose, glucose, fructose, cellobiose, maltose, sucrose, trehalose and turanose and activities of esterase lipase (C8) and leucine arylamidase, All are negative for hydrolysis of hypoxanthine and urea, utilization of glycerol, erythritol, D-arabinose, L-xylose, adonitol, mannose, sorbose, dulcitol, sorbitol, salicin, inulin, raffinose, glycogen, xylitol, D-fucose, citrate and phenylacetate and activities of lipase (C14), valine arylamidase, $\alpha$-chymotrypsin, $\alpha$-galactosidase, $\beta$-glucosidase, $\beta$-glucuronidase, $N$-acetyl- $\beta$-glucosaminidase, $\alpha$-mannosidase and $\alpha$-fucosidase.

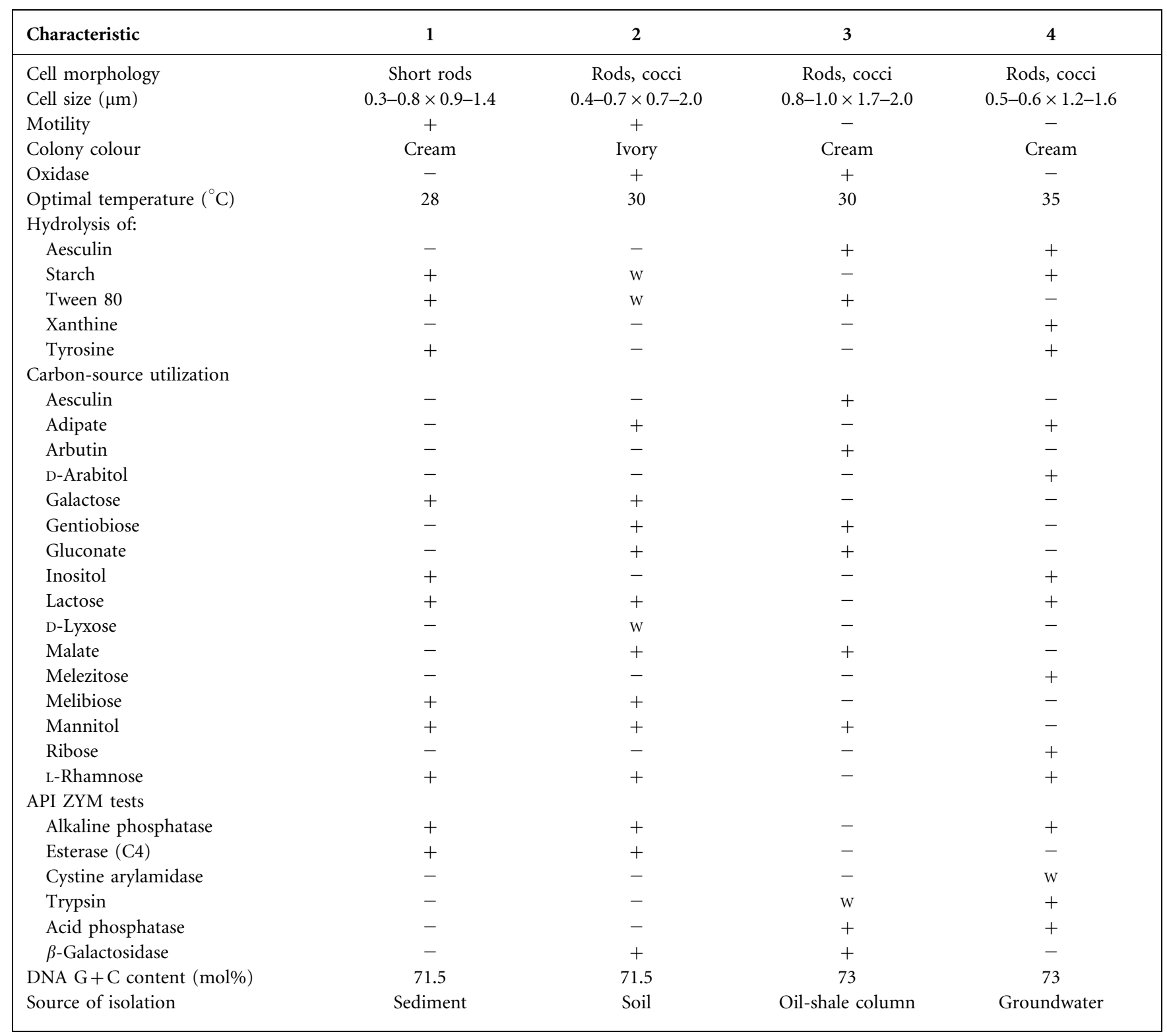

alkaline phosphatase, esterase (C4), esterase lipase (C8) and leucine arylamidase. Negative for lipase (C14), valine arylamidase, cystine arylamidase, trypsin, $\alpha$-chymotrypsin, acid phosphatase, naphthol-AS-BI-phosphohydrolase, $\alpha$-galactosidase, $\beta$-galactosidase, $\beta$-glucuronidase, $\alpha$-glucosidase, $\beta$-glucosidase. $N$-acetyl- $\beta$-glucosaminidase, $\alpha$-mannosidase and $\alpha$-fucosidase. Uses cellobiose, fruct- ose, galactose, glucose, inositol, lactose, melibiose, mannitol, mannose, maltose, rhamnose, sucrose, trehalose, turanose and xylose as sole carbon and energy sources, but not arabinose, aesculin, adonitol, adipate, Darabitol, arbutin, dulcitol, erythritol, D-fucose, gentiobiose, gluconate, glycerol, glycogen, inulin, D-lyxose, mannose, malate, melezitose, raffinose, ribose, salicin, 


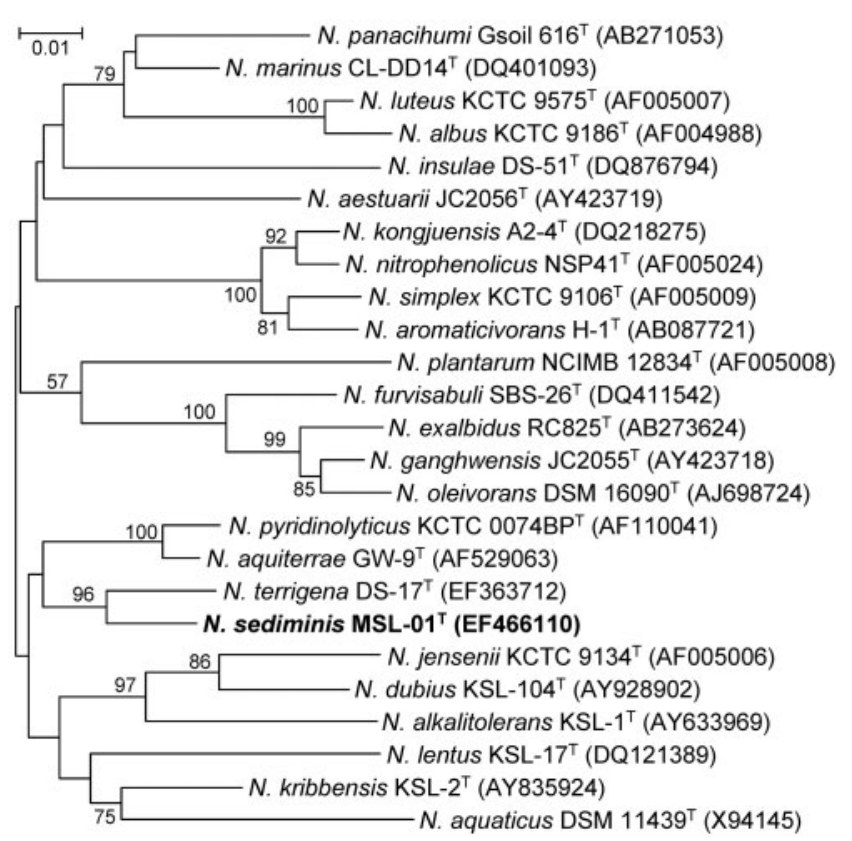

Fig. 2. Neighbour-joining phylogenetic tree based on $16 \mathrm{~S}$ rRNA gene sequences showing the positions of strain $\mathrm{MSL}-01^{\top}$ and related taxa. Bootstrap values (expressed as percentages of 1000 replications) $>50 \%$ are shown at branch points. Bar, 0.01 substitutions per nucleotide position.

sorbose, sorbitol, xylitol or L-xylose. Acid is not produced from any of the carbon sources tested. The main cell-wall amino acid is LL-diaminopimelic acid. The predominant menaquinone is $\mathrm{MK}-8\left(\mathrm{H}_{4}\right)$. The major cellular fatty acids are iso- $\mathrm{C}_{16: 0}, \mathrm{C}_{17: 1} \omega 8 c$, iso- $\mathrm{C}_{17: 0}, 10$-methyl $\mathrm{C}_{17: 0}$ and $\mathrm{C}_{18: 1} \omega 9 c$. The DNA $\mathrm{G}+\mathrm{C}$ content of the type strain is $71.5 \mathrm{~mol} \%$.

The type strain, MSL- $01^{\mathrm{T}} \quad\left(=\mathrm{DSM} \quad 19263^{\mathrm{T}}=\mathrm{KCTC}\right.$ $\left.19271^{\mathrm{T}}\right)$, was isolated from a sediment sample collected from Bigeum Island in South Korea.

\section{Acknowledgements}

This work was supported by the 21C Frontier Microbial Genomics and Application Centre program of the Korean Ministry of Science \& Technology (MOST) and the Korea Foundation for International Cooperation of Science \& Technology (KICOS) through a grant provided by the MOST in Global Partnership Program (no. M60602000001-06E0200-00100), Republic of Korea.

\section{References}

Becker, B., Lechevalier, M. P. \& Lechevalier, H. A. (1965). Chemical composition of cell-wall preparations from strains of various formgenera of aerobic actinomycetes. Appl Microbiol 13, 236-243.

Chun, J. \& Goodfellow, M. (1995). A phylogenetic analysis of the genus Nocardia with 16S rRNA gene sequences. Int J Syst Bacteriol 45, 240-245.
Collins, M. D., Pirouz, T., Goodfellow, M. \& Minnikin, D. E. (1977). Distribution of menaquinones in actinomycetes and corynebacteria. $J$ Gen Microbiol 100, 221-230.

Cowan, S. T. \& Steel, K. J. (1965). Manual for the Identification of Medical Bacteria. London: Cambridge University Press.

Felsenstein, J. (1981). Evolutionary trees from DNA sequences: a maximum likelihood approach. J Mol Evol 17, 368-376.

Kämpfer, P. \& Kroppenstedt, R. M. (1996). Numerical analysis of fatty acid patterns of coryneform bacteria and related taxa. Can J Microbiol 42, 989-1005.

Kluge, A. G. \& Farris, J. S. (1969). Quantitative phyletics and the evolution of anurans. Syst Zool 18, 1-32.

Komagata, K. \& Suzuki, K. (1987). Lipid and cell-wall analysis in bacterial systematics. Methods Microbiol 19, 161-207.

Lányí, B. (1987). Classical and rapid identification methods for medically important bacteria. Methods Microbiol 19, 1-67.

Lechevalier, M. P. \& Lechevalier, H. A. (1980). The chemotaxonomy of actinomycetes. In Actinomycete Taxonomy, pp. 227-291. Special Publication no. 6. Edited by A. Dietz \& D. W. Thayer. Arlington, VA: Society for Industrial Microbiology.

Lechevalier, M. P., Stern, A. E. \& Lechevalier, H. A. (1981). Phospholipids in the taxonomy of actinomycetes. Zentralbl Bakteriol Hyg Abt 1 Suppl 11, 111-116.

Lee, D. W., Hyun, C.-G. \& Lee, S. D. (2007). Nocardioides marinisabuli sp. nov., a novel actinobacterium isolated from beach sand. Int J Syst Evol Microbiol 57, 2960-2963.

Prauser, H. (1976). Nocardioides, a new genus of the order Actinomycetales. Int J Syst Bacteriol 26, 58-65.

Prauser, H. (1984). Nocardioides luteus sp. nov. Z Allg Mikrobiol 24, 647-648.

Reasoner, D. J. \& Geldreich, E. E. (1985). A new medium for the enumeration and subculture of bacteria from potable water. Appl Environ Microbiol 49, 1-7.

Saitou, N. \& Nei, M. (1987). The neighbor-joining method: a new method for reconstructing phylogenetic trees. Mol Biol Evol 4, 406425.

Sasser, M. (1990). Identification of bacteria by gas chromatography of cellular fatty acids. USFCC Newsl 20, 16.

Shirling, E. B. \& Gottlieb, D. (1966). Methods for characterization of Streptomyces species. Int J Syst Bacteriol 16, 313-340.

Tamaoka, J. \& Komagata, K. (1984). Determination of DNA base composition by reversed-phase high-performance liquid chromatography. FEMS Microbiol Lett 25, 125-128.

Thompson, J. D., Higgins, D. G. \& Gibson, T. J. (1994). CLUSTAL W: improving the sensitivity of progressive multiple sequence alignment through sequence weighting, position-specific gap penalties and weight matrix choice. Nucleic Acids Res 22, 4673-4680.

Tóth, E. M., Kéki, Z., Homonnay, Z. G., Borsodi, A. K., Márialigeti, K. \& Schumann, P. (2008). Nocardioides daphniae sp. nov., isolated from Daphnia cucullata (Crustacea: Cladocera). Int J Syst Evol Microbiol 58, 78-83.

Wayne, L. G., Brenner, D. J., Colwell, R. R., Grimont, P. A. D., Kandler, O., Krichevsky, M. I., Moore, L. H., Moore, W. E. C., Murray, R. G. E. \& other authors (1987). International Committee on Systematic Bacteriology. Report of the ad hoc committee on reconciliation of approaches to bacterial systematics. Int J Syst Bacteriol 37, 463-464.

Yoon, J.-H. \& Park, Y.-H. (2006). The genus Nocardioides. In The Prokaryotes: a Handbook on the Biology of Bacteria, 3rd edn, vol. 3, 1099-1113. Edited by M. Dworkin, S. Falkow, E. Rosenberg, K. H. Schleifer \& E. Stackebrandt. New York: Springer. 
Yoon, J. H., Rhee, S. K., Lee, J. S., Park, Y. H. \& Lee, S. T. (1997). Nocardioides pyridinolyticus sp. nov., a pyridine-degrading bacterium isolated from the oxic zone of an oil shale column. Int J Syst Bacteriol 47, 933-938.

Yoon, J. H., Kim, I. G., Kang, K. H., Oh, T. K. \& Park, Y. H. (2004).

Nocardioides aquiterrae sp. nov., isolated from groundwater in Korea. Int J Syst Evol Microbiol 54, 71-75.
Yoon, J.-H., Kang, S.-J., Lee, S.-Y. \& Oh, T.-K. (2007). Nocardioides terrigena sp. nov., isolated from soil. Int J Syst Evol Microbiol 57, 2472-2475.

Yoon, J.-H., Kang, S.-J., Lee, M.-H. \& Oh, T.-K. (2008). Nocardioides hankookensis sp. nov., isolated from soil. Int J Syst Evol Microbiol 58, 434-437. 